\title{
Effects of Global Warming of ICT Products in the Philippines
}

Las Johansen B. Caluza

ORCID No. 0000-0003-4353-6916 Leyte Normal University

\begin{abstract}
Technology as a spectrum in the economy plays a vital role in the understanding and adaptation of a changing world vis a vis climate change and its effects. This study explores the inclination of ICT in the Philippines about climate change and its effects. The Data mining was utilized in the exploration of information and knowledge, specifically the use of association rule. Findings revealed that there was a rise of export services of ICT in the Philippines despite being a front line of natural disasters in the world. Finally, a theory was developed by the researcher about ICT and climate change.
\end{abstract}

Key words: Climate change, ICT, association rule, data mining, exports, imports, trends, Philippines.

\section{Introduction}

Information Technology is a factor of economic growth of a state. Many of these countries produce technological machines that significantly contribute to others who are in need of its services. This study would like to explore through data mining information of ICT (information, and communication technology) products produce for exports and imports, its economic impact, and services rendered in the Philippines by climate change. In the Philippines, the NEDA (Nation alEconomic and Development Agency) through the former Philippine President initiated the National Framework Strategy on Climate Change [1] stated its impacts and vulnerability. As mentioned in the said framework that "climate change in the country triggered the rise in temperature and the increases in variability and pattern of rainfall and super typhoon events, as well.” Anent to this, Forbes reported as "Climate Change Threatens Economic Growth-UN Report. How Investors React?” the UN's IPCC (intergovernmental panel on climate

Corresponding author: Las Johansen B. Caluza, Ph. D, research fields: data mining, text mining, fractal statistics, database management systems, information systems, software engineering, educational technology (eLearning, blended learning, m-Learning), and other social science research. change) could not be clearer - climate change is a risk to economic growth. It is in this statement that the study is conducted if there is an effect of climate change in economic growth of the state about ICT import and export services [2]. In this study, data mining technique was used to determine if there is a relationship between ICT products being imported and exported and other services and the climate change that the Philippines experienced.

\section{Conceptual Framework}

This study adopted the IPO (input-process-output) framework where variables are obtainable and were carefully selected by the researcher to develop a theory.

\section{Methodology}

\subsection{Research Design}

The research design employed by the research was quantitative using exploratory researchdesign; this was used to test the data obtained from the source using data mining specifically using the association rule technique.

\subsection{Research Methods}

The researcher gathers information from the PAGASA 


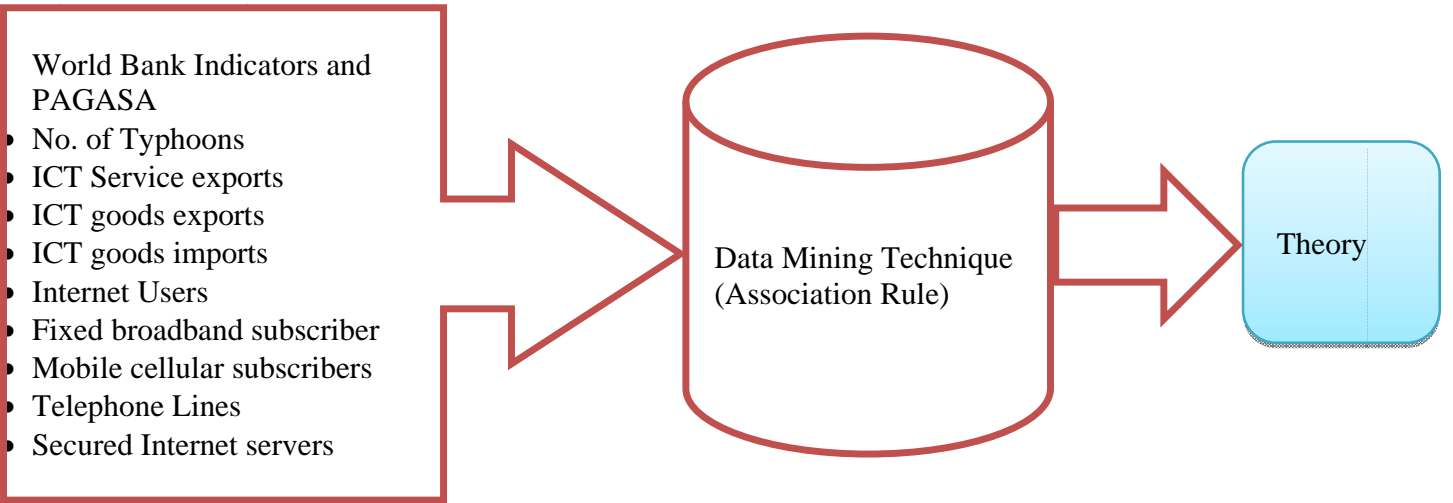

Fig. 1 A conceptual framework on ICT trends in the Philippines relative to climate change.

(Philippine atmospheric, geophysical and astronomical services administration) — the number of typhoons that enter the PAR (Philippine area of responsibility) and from World Bank Organization website using the indicators about ICT for the past eight years. Data mining, specifically an association rule technique was used to generate new information. Data Mining is a logical process designed to explore data [3, 4]. Moreover, data mining, also called knowledge discovery in databases [5].

Itemset - a collection of one or more items.

Support Count $(\boldsymbol{\sigma})$ - frequency of occurrence of an itemset.

Support-fraction of transactions that contains an itemset.

Frequent itemset-an itemset whose support is greater than or equal to a minsup threshold.

Association Rule-an implication of the form $\mathrm{X} \rightarrow$ $\mathrm{Y}$, where and $\mathrm{Y}$ are itemsets.

\section{Rule Evaluation Metrics}

Support (s)-Fraction of transaction that contains both and Y.

Confidence-Measures how often itemsets in $\mathrm{Y}$ appear in transactions that contain X.

Minimum Support (Minsup) —is one more than half the number of cases. In this research, since the number of the item is eight then the minsup is five.

In reducing the number candidates, the researcher employs apriori principle which means "If an itemset is frequent, then all of its subsets must also be frequent" [6]. Apriori principle holds due to the following property of the support measure:

$$
\forall X, Y:(X \subseteq Y) \Rightarrow s(X) \geq s(Y)
$$

where support of an itemset never exceeds the supports of its subsets and is known as the anti-monotone property of support.

\section{Presentation of Data and Results}

Table 1 shows the eight years of datasets from 2005 to 2012 taken from the PAGASA and the World Bank organization website $[7,8]$.

Table 2 shows above where the coding technique and its descriptions employed by the researcher to quickly identify and analyzed the variables utilized in the research.

Table 3 illustrates the use of association rule by comparing the values of variables to the mean (please see Table 1) per year and denoting it by 1 's if it is greater than or equal to the mean and 0's if it is less than the mean.

Table 4 shows the transcription of values denoted by 1 's to its variable codes.

Table 5 exemplifies the distribution of item 1 set using the frequent item set generation rule and rule generation in association rule. In itemset 1 the variable $B$, denoted as ICT service exports (\% of service exports- $-\mathrm{BoP}$ ) is accepted since it is equal to the mins up which is five, and the rest of the variables are disregarded since it did not meet the minsup. 
Table 1 Distribution of values of the variables by year.

\begin{tabular}{|c|c|c|c|c|c|c|c|c|c|}
\hline Years & $\frac{\text { No. of }}{\text { Typhoons }}$ & \begin{tabular}{|c|}
$\frac{\text { ICT }}{\text { service }}$ \\
$\underline{\text { exports }}$ \\
$\begin{array}{l}\text { l\% of } \\
\text { service }\end{array}$ \\
exports - \\
\end{tabular} & \begin{tabular}{|c|} 
ICT goods \\
exports \\
(\% of \\
total \\
goods \\
exports)
\end{tabular} & 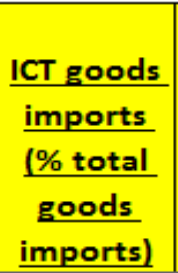 & $\begin{array}{c}\frac{\text { Internet }}{\text { users }} \\
\text { (per 100 } \\
\text { people) }\end{array}$ & $\begin{array}{c}\begin{array}{c}\text { Fixed } \\
\text { broadban }\end{array} \\
\frac{\text { d Internet }}{\text { subscriber }} \\
\frac{\text { s }}{}\end{array}$ & $\frac{\frac{\text { Mobile }}{\text { cellular }}}{\text { subscripti }}$ & $\begin{array}{c}\text { Telephone } \\
\text { Lines }\end{array}$ & $\begin{array}{l}\text { Secured } \\
\text { Internet } \\
\text { servers }\end{array}$ \\
\hline 2005 & 17 & 15.92 & 47.67 & 45.81 & 5.4 & 123000 & 34778995 & 3367252 & 210 \\
\hline 2006 & 20 & 17.70 & 47.76 & 44.18 & 5.74 & 265030 & 42868911 & 3633188 & 283 \\
\hline 2007 & 13 & 27.51 & 33.71 & 42.68 & 5.97 & 496151 & 57344815 & 3940082 & 350 \\
\hline 2008 & 22 & 50.71 & 30.59 & 33.70 & 6.22 & 1045716 & 68117167 & 4076140 & 413 \\
\hline 2009 & 23 & 61.47 & 36.42 & 33.20 & 9.00 & 1722407 & 75586646 & 4100000 & 484 \\
\hline 2010 & 12 & 63.47 & 26.77 & 31.63 & 25.00 & 1722400 & 83150138 & 3335398 & 622 \\
\hline 2011 & 21 & 71.69 & 22.74 & 13.16 & 29.00 & 1791000 & 94189795 & 3555951 & 716 \\
\hline 2012 & 17 & 67.28 & 29.47 & 24.75 & 36.24 & 2146600 & 101978345 & 3493164 & 834 \\
\hline SUM & 145 & 375.76 & 275.13 & 269.11 & 122.57 & 9312304 & 558014812 & 29501175 & 3912 \\
\hline MEAN & 19 & 48 & 35 & 35 & 16 & 1164039 & 69751853 & 3687648 & 490 \\
\hline
\end{tabular}

Table 2 Distribution of coding values of the variables.

\begin{tabular}{|c|c|c|}
\hline Code & $\begin{array}{l}\text { The World Development } \\
\text { Indicators }\end{array}$ & Description \\
\hline A & Number of typhoons & $\begin{array}{l}\text { Number of Typhoons, Tropical Storm, and Tropical Depression entered the Philippines Area of } \\
\text { Responsibility (PAR) }\end{array}$ \\
\hline B & $\begin{array}{l}\text { ICT service exports } \\
\text { (\% of service exports - BoP) }\end{array}$ & $\begin{array}{l}\text { Information and communication technology service exports include computer and } \\
\text { communications services (telecommunications and postal and courier services) and } \\
\text { information services (computer data and news-related service transactions). }\end{array}$ \\
\hline $\mathrm{C}$ & $\begin{array}{l}\text { ICT goods exports } \\
\text { (\% of total goods exports) }\end{array}$ & $\begin{array}{l}\text { Information and communication technology goods exports include telecommunications, audio } \\
\text { and video, computer and related equipment; electronic components; and other information and } \\
\text { communication technology goods. }\end{array}$ \\
\hline $\mathrm{D}$ & $\begin{array}{l}\text { ICT goods imports } \\
\text { (\% total goods imports) }\end{array}$ & $\begin{array}{l}\text { Information and communication technology goods imports include telecommunications, audio } \\
\text { and video, computer and related equipment; electronic components; and other information and } \\
\text { communication technology goods. }\end{array}$ \\
\hline $\mathrm{E}$ & $\begin{array}{l}\text { Internet users } \\
\text { (per } 100 \text { people) }\end{array}$ & Internet users are people with access to the worldwide network. \\
\hline $\mathrm{F}$ & $\begin{array}{l}\text { Fixed broadband Internet } \\
\text { subscribers }\end{array}$ & $\begin{array}{l}\text { Fixed broadband Internet subscribers are the number of broadband subscribers with a digital } \\
\text { subscriber line, cable modem, or other high-speed technology. }\end{array}$ \\
\hline G & $\begin{array}{l}\text { Mobile cellular } \\
\text { subscriptions }\end{array}$ & $\begin{array}{l}\text { Mobile cellular telephone subscriptions are subscriptions to a public mobile telephone service } \\
\text { using cellular technology, which provide access to the public switched telephone network. } \\
\text { Postpaid and prepaid subscriptions are included. }\end{array}$ \\
\hline $\mathrm{H}$ & Telephone Line & $\begin{array}{l}\text { Telephone lines are fixed telephone lines that connect a subscriber's terminal equipment to the } \\
\text { public switched telephone network and that have a port on a telephone exchange. Integrated } \\
\text { services, digital network channels, and fixed wireless subscribers are included. }\end{array}$ \\
\hline $\mathrm{I}$ & Secured Internet servers & Secure servers are servers using encryption technology in Internet transactions. \\
\hline
\end{tabular}

Table 3 Distribution of values of variables using association rules.

\begin{tabular}{llllllllll}
\hline$\underline{\mathrm{NO}}$ & $\underline{\mathrm{A}}$ & $\underline{\mathrm{B}}$ & $\underline{\mathrm{C}}$ & $\underline{\mathrm{D}}$ & $\underline{\mathrm{E}}$ & $\underline{\mathrm{F}}$ & $\underline{\mathrm{G}}$ & $\underline{\mathrm{H}}$ & $\underline{\mathrm{I}}$ \\
\hline 1 & 0 & 0 & 1 & 1 & 0 & 0 & 0 & 0 & 0 \\
2 & 1 & 0 & 1 & 1 & 0 & 0 & 0 & 0 & 0 \\
3 & 0 & 0 & 0 & 1 & 0 & 0 & 0 & 1 & 0 \\
4 & 1 & 1 & 0 & 0 & 0 & 0 & 0 & 1 & 0 \\
5 & 1 & 1 & 1 & 0 & 0 & 1 & 1 & 1 & 0 \\
6 & 0 & 1 & 0 & 0 & 1 & 1 & 1 & 0 & 1 \\
7 & 1 & 1 & 0 & 0 & 1 & 1 & 1 & 0 & 1 \\
8 & 0 & 1 & 0 & 0 & 1 & 1 & 1 & 0 & 1 \\
\hline
\end{tabular}


Table 4 Transcription of values using codes.

\begin{tabular}{ll}
\hline $\mathrm{NO}$ & $\underline{\text { ITEM }}$ \\
\hline 1 & C,D \\
2 & A,C,D \\
3 & D,H \\
4 & A,B,H \\
5 & A,B,C,F,G,H \\
6 & B,E,F,G,I \\
7 & A,B,E,F,G,I \\
8 & B,E,F,G,I \\
\hline
\end{tabular}

Table 5 Distribution of items and it's supports.

\begin{tabular}{ll}
\hline ITEM 1 SET & $\underline{\text { Support }}$ \\
\hline A & 4 \\
B & 5 \\
C & 3 \\
D & 3 \\
E & 3 \\
F & 4 \\
G & 4 \\
H & 3 \\
I & 3 \\
\hline
\end{tabular}

\section{Hypotheses}

Established in the data presented and analyzed above, it is speculated that there is an increase of ICT service exports relative to climate change.

\section{Conclusion/Theory}

Meteorological condition is associated with the growth of technology service trades.

\section{References}

[1] Climate Change. 2010. National Framework Strategy on Climate Change 2010-2022. Retrieved on 10/11/2014 from http://www.neda.gov.ph/wp-content/uploads/2013/10/nfs cc_sgd.pdf.

[2] Scott, M. 2014. Climate Change Threatens Economic Growth - UN Report. Investors React?. Forbes. Retrieved on 10/11/2014 from http://www.forbes.com /sites/mikescott/2014/04/03/climate-change-threatens-eco nomic-growth-un-report-how-should-investors-react/.

[3] Data Mining. (n. d.). Statistics Textbook. Dell. Retrieved on 10/11/2014 from http://www.statsoft.com/textbook/data-mining-technique.

[4] Dell. 2015. Data Mining Techniques. Statistics Textbook. Retrieved on 5/8/2015 from http://documents.software.dell.com/statistics/textbook/dat a-mining-techniques.

[5] Clifton, C. (n.d.). Data Mining. Encyclopedia Britannica. Retrieved on 10/11/2014 from http://www. britannica.com/EBchecked/topic/1056150/data-mining.

[6] Padua, R. (n.d.). Advanced Research Module: Data Mining. Power Point Presentation.

[7] World Bank Organization. (n.d.). Retrieved on 10/6/2014 fromhttp://data.worldbank.org/indicator.

[8] Trading Economics. (n.d.). Retrieved on 10/6/2014 from http://www.tradingeconomics.com/philippines/. 